\title{
The Problems the Students Faced in Technical Translation Course at the Hashemite University: An Overview
}

\author{
Mai Malkawi \\ The language center, The Hashemite University, P.O. Box 330127, Zarqa 13133, Jordan
}

\begin{abstract}
This paper aims at investigating the problems facing the students of The Hashemite University who took the technical translation course. After studying and analyzing some samples of students' translations throughout the course, it is discovered that there are three main problems encountered:

- Problems related to word order and sentence structure.

- Word choice

- Grammatical problems

My hypothesis is that those problems are present in a more less frequency in the translations done by students coming from scientific and medical collages especially when those students are of the third year and above.

Keywords: Hashemite University, technical translation, problems

DOI: $10.7176 /$ RHSS/11-2-08

Publication date: January $31^{\text {st }} 2021$

1. Introduction

Technical translation is an elective course offered by the Language Center to the students of The Hashemite University starting from the fall semester of the academic year 2011/2012. The course is divided into two parts: Theoretical and practical. In the theoretical part, the students are given theoretical information about translation starting from the definition of translation, the concept of equivalence, types of translation and strategies of translation arriving at the role of the dictionaries in the process of translation.

Then, as it is the core of this course, the concept of Technical Translation is introduced to the students by contrasting technical texts with other types of texts as: expository, persuasive, and expressive.

Upon finishing the theoretical part, the practical part starts by dividing the students into groups of 3 or 4 in order to work together all through the semester. During this part, students translate technical texts from English into Arabic and vice versa.
\end{abstract}

\section{What is Technical Translation?}

Before we go and discuss the notion of technical translation, let's start with giving some information about translation in general. "Translation is often regarded as a process for transferring meaning from one language to another." (Farghal and Shunnaq: 2011). As it can be understood from this definition, translation - as it is an interlingual activity- involves two different languages; SL (source language) and TL (target language). The translator necessarily have to be competent in the two languages, otherwise, the product will be of a bad quality in a part or whole. In addition, it should be noticed also that the translation process encompasses more than merely finding a substitute for a lexical item, instead the substitute (equivalent) in the TL must reflect all the aspects of the SL expression; the structural, the social and the cultural as well.

As a type of translation, technical translation is the translation of scientific and specialized texts that contain the terminology and the jargon of that science. This requires from the translator to have great knowledge in the subject matter translated

\section{Methodology}

\subsection{The study sample}

For the purpose of this study, the students of technical translation course at the Hashemite University at the summer semester 2018/2019 were taken as a sample for the research. They were (24) students coming from different specialties and majors and from different years. The distribution of students' specialties and studying years are shown in the following tables. 
Table 1. Students' Majors

\begin{tabular}{|l|l|}
\hline The field & Number of students \\
\hline Medical students & 5 \\
\hline Engineering students & 9 \\
\hline Nutrition students & 1 \\
\hline English Language students & 1 \\
\hline Business students & 3 \\
\hline Geology students & 1 \\
\hline Pharmaceutical sciences students & 1 \\
\hline Medical imaging students & 2 \\
\hline International relation and strategic studies students & 1 \\
\hline TOTAL & 24 \\
\hline
\end{tabular}

Table 2. Students' Studying Years

\begin{tabular}{|l|l|}
\hline Studying years & Number of students \\
\hline Freshmen year & 6 \\
\hline sophomores & 7 \\
\hline Junior & 5 \\
\hline seniors & 6 \\
\hline TOTAL & 24 \\
\hline
\end{tabular}

\subsection{Data collection process}

The researcher used two methods for data collection. The first method is exams where the students were given some texts (Arabic and English) and were asked to translate them. The second method is a questionnaire. In this process the students were asked to answer 10 questions related to the topics of the research interest. The aim of the questionnaire is to support the analysis of translation in the first phase.

\section{Data analysis}

\subsection{Translation From English into Arabic}

The first stage of the study included giving the students some technical texts (Arabic and English) and asking them to translate them into the other language. Based on the data gained after this stage, the following problems were found throughout the texts translated from English into Arabic:

\section{- $\quad$ Structure and Word Order}

As Arabic and English belong to two different families, and as Mahasneh wrote in her paper 2016:

"Arabic belongs to the Semitic group of languages, whereas English is a West Germanic language. Arabic culture and English or Western cultures are also different in many ways."

Thus, it is understandable and expected that structural mismatches are a challenge for the translator that need to be overcome or it will distort the product that is, thetarget text. This was a problem faced by the students when they translated English texts into Arabic. The sentence in Arabic is generally a verbal sentence i.e. it starts with a verb, but it can be a nominal sentence starting with a subject if the focus or the topic is put on the noun. This is what makes these two sentences different:

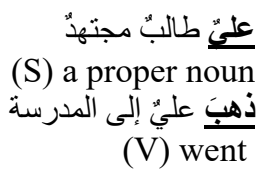

In the first sentence which literally means Ali is a hardworking student, the underlined word is the proper noun (Ali) that is the subject. The focus in this sentence and its topic is (Ali) to show that it talks about Ali not some else. While in the second sentence which is verbal starts with the underlined verb which means (went). The sentence literally means (went Ali to school) and as it can be noticed the sentence starts with the verb as it is the important part and the main idea to be conveyed through the sentence. Thus, the sentence points out that Ali WENT to the school not did homework for example.

On the other hand, the English sentence is nominal i.e. it always starts with a noun or a pronoun (subject) and it never starts with a verb sure except for in imperative sentences. This difference was unclear for some students as it is noticed from the students' translations of the sentences and texts given to them leading to incorrect and unnatural renditions. An example to show such a problem is the rendition of:

When nitrogen unites with hydrogen to form ammonia into:

عندما النيتروجين يتحد مع الهيدروجين ليكون الأمونيا

Here some students started their translation with the noun النيترون النين making the product sentence nominal which is 
unnatural in Arabic in this case. The reason of the unnaturalness here is the fact that in this context we are focusing on the action (verb) rather that the noun. The text is all about nitrogen, so there is no need to put it at the beginning of the sentence. What matters here is the action (verb) happening to nitrogen. Consequently, the verb يتحد should be the focus of the sentence and thus should be placed at the beginning making the sentence:

عندما يتحد النيتروجين مع الهيدروجين ليكون الأمونيا .

\section{- Word Choice}

The second and highly recurrent problem found in students' translation from English to Arabic is having the right word choice, that is, choosing the right and suitable equivalent. As a core concept of translation, equivalence is Thus, when choosing the equivalent, the translator must make sure that the same effect should be conveyed in the target text. This point is highly important especially in technical texts . For example, if we translate "Sodium is shiny chemical element" into (الصودبو معدن مشع) , the meaning between the SL and TL is extremely different due to the different connotation between (shiny) and (مشع ). While shiny has many Arabic equivalents all of which have almost the same meaning such as: براق , لامع , متلالئ, مشع , ساطع) in a context in chemistry, the translator should be aware of the equivalent chosen. Though مشع : مشع is one of the meanings for shiny, it is not the right, precise equivalent in this very context as it means radioactive when it is used in the jargon of chemistry which is incorrect due to the fact that sodium actually is not a radioactive element. Thus, the translator must opt for (لامع () which means (bright) the opposite of dark.

Students in some cases failed to arrive at the correct equivalent from the different meanings of some words. To clarify, students came up with many different translations for the word “ introduction” as: بداية, مقدمة , داخل, دخول in the sentence (Pollution is the introduction of contaminants into the environment). All of those Arabic equivalents are correct meanings of the word (introduction) (The dictionary 2004). However, the translator should choose the most suitable one, in this case (دخول) as the other words do not convey the intended meaning because the word

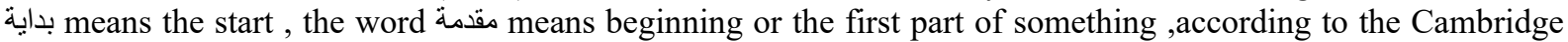
dictionary. and داخل means interior.

Another example is the translation is the translation of the word (drugs) in the sentence " one of the most dangerous drugs for a pregnant woman to consume is alcohol.". Students came up with different translations such as:مو اد , عقاقير, عقار ات, مخدرات,ممنو عات,which are all right meanings for the word drug. If the translator takes the context into consideration, the precise equivalent that conveys the meaning is مواد which means substance. The other words, though have the same meaning, do not fit this context as عقاقير means "medication" (The dictionary: 2004), عقار ات "real estate" (The dictionary :2004), and مخدر ات,ممنو عات which mean " narcotic substances".

A third example is the rendition of the verb (is concerned) in the sentence "Geology i.e. is concerned with the study of those processes that relate to the origins of minerals.". Also here , some students were unsuccessful in putting the right equivalent for the verb "is concerned" as they translated it to : قلق , لديه مخاوف meaning to have fears. The correct rendition should be: متعلق ب , sهich mean involves and interested in.

A new example is "As a pregnant woman drinks alcohol, the alcohol is passed into her bloodstream almost simultaneously.". Here some students faced a problem translating the linking word "as" and the verb "drinks". Regarding "as", it has many meanings depending on its context. Thus, it can be a connector of time such as in the sentence "We all waved to Liza as she drove away."(Murphy:2012) or it can be a connector of manner as in " You s hould have done it as I showed you." (Murphy:2012) and it may mean because like in the sentence "As I was hungry, I decided to find somewhere to eat." (Murphy: 2012). In each sentence, this connector has a different equivalent in Arabic which requires understanding the context in order to come up with the right one. When it is a connector of time it means عندما , بينما, while when it is a connector of cause it means لأن, بسبب, and when it is a connector of manner it is كما, ك5 meaning 'similar to', 'the same as' (Murphy: 2012). It is clear that in this sentence, it is a time connector that shows the time of the occurrence of the action or more specifically "when two things happen at the same time." (Murphy:2012), so the best rendition her is عis. Some students were unable to arrive to the right equivalent for this connector thus considering it of cause or of manner.

The other problem faced in this sentence is the verb "drinks" that some students translated as . Though the core meaning of يحتسي is drink, it is inappropriate to consider it as an equivalent here. In Arabic, يحتسي means (to sip) which means to drink with passion or thoughtfully and in a relaxing atmosphere. For example if we translated "He drinks his coffee every morning while he is listening to music into: يحتسي قهوته كل صباح وهو يستمع it will be right. However, in a scientific text discussing the negative effects of drinking alcohol, the neutral verb يشرب best fits the context.

\section{- Arabicization}

In order for the translation product to be effective achieving its ultimate goal, the translator should opt for the natural and understandable equivalent for the SL expression. According to farghal and Shunnaq 2011 " As for Arabicization, it is a kind of naturalization that takes place either at the sound level where SL spelling and pronunciation are converted into Arabic ones or at the concept level where an SL concept is loan - translated into Arabic.". Based on this, Arabicization can be done in two levels the pronunciation and the concept the matter that makes the SL expression more Arabic. To clarify, we can translate a word like (telescope) into Arabic following 
these two levels as: (تيليسكوب) and (المقراب) where telescope is arabcized using, at one time, the pronunciation level by borrowing the English word and then making some modifications in order to give its Arabic flavor while the latter is the Arabicized version of the expression by the use of the concept rather than the pronunciation resulting in a pure Arabic word - المقراب.

While studying the translations of the students, I found some students opted for Arabicization as a way to translate some expressions they may find difficult or they do not know how to translate them. One of the examples is the translation of the word (geyser) in the sentence "A geyser is the result of underground water under the combined conditions of high temperature and increased pressure beneath the surface of the Earth." which is translated by some students as (جيزر) which is a borrowed word and which is not the suitable and the right equivalent. The reason for this is that, as an equivalent for geyser, the borrowed word (جيزر) is used in Arabic to mean "an apparatus for heating water rapidly with a gas flame (as for a bath)" (Mariam Webster) while the meaning expressed in the sentence is" a spring that throws forth intermittent jets of heated water and steam" (Mariam Webster). Thus, instead of (جيزر) , students should have chosen (نبع الماء الساخن) as the precise equivalent for geyser in this sentence.

Another example is the translation of the expression nucleic acid in the sentence" the control of protein synthesis itself is dominated by the nucleic acids. Some students translated it as: أسيد النيكليوك : and others translated it as Both translations which are borrowed words are wrong because these renditions are not natural and are not normally used in Arabic, instead the best translation is الحمض النووي

\subsection{Translation From Arabic into English}

In the part where the students translated texts from Arabic into English also some problems were noticed mainly problems with structure and word order and problems with word choice.

\section{$\bullet$}

Structure and Word Order

As said previously, there are lots of structural differences between Arabic and English due to the fact that they belong to two different families of languages. This problem is even more recurrent in this part as the mother tongue of the students is not English. An example is found in the translation of the Arabic sentence: قالت عالمة الإجتماع into "said the sociologist". The Arabic sentence starts with قالت which is a verb and the word عالمة الإجتماع whe wh the subject and when translated into English it should be "The sociologist said" in order to make it follow the correct English structure.

\section{- Word choice}

As expected, choosing the right equivalent is the greatest challenge that faces the translator and this challenge becomes greater if the TL is not the translator's mother tongue. Many examples can illustrate and show the difficulty faced by the students in translating some expressions.

The first example is this sentence which was sort of problematic for them:

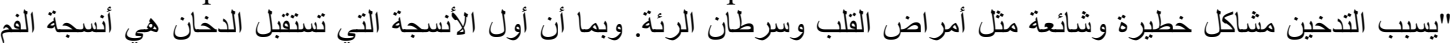

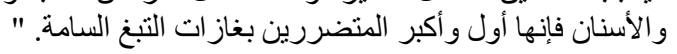

http://www.meshaldental.net/home/?p=1742

The first problem the students faced was the word شائعة which is a word that has more than one meaning depending on the context where it appears. Some students translated it as (rumor) which is a wrong translation. According to Al mawrid dictionary the word شائعة has many different meanings such as: widespread, current, prevailing, common , known, and rumor. The correct equivalent is common and thus the translation of this part of the sentence should be "Smoking causes dangerous and common problems " and sure not " rumor problems". Also the expression أمر اض القلب confused the students and made them translate it as cardiology instead of heart diseases. The problem here is that the students mixed the two ways to express the meaning of أمر اض القلب as it means the the science that studies heart diseases (cardiology) or the diseases that affect the heart which is the meaning intended in this sentence.

Another expression that was also problematic for the students is الأنسجة which is an expression with multiple meanings based on the context. According to Al mawrid, it means textile, texture, fabric, cloth and tissue. Some students translated it as "body fabrics" "body textiles" which are totally wrong equivalents here. The words fabric and textile refer to cloth and thus cannot be used in the context in the sentence above which is medical where the word tissues which is associated with the context of the human body should be used.

\section{The survey}

To support the ideas presented previously, a survey was conducted-using Google forms- on the students taking the technical translation course at The Hashemite University. The survey contained 10 questions covering translation problems they face during the translation process like word choice, structure, and grammar. The first question was Structural mismatches are the main obstacle that prevents accurate translation. Structural mismatches are the main obstacle that prevents accurate translation.(Structural mismatches is the main obstacle that prevents accurate translation.) 
3. Structural mismatches are the main obstacle that prevents accurate translation.

29 responses
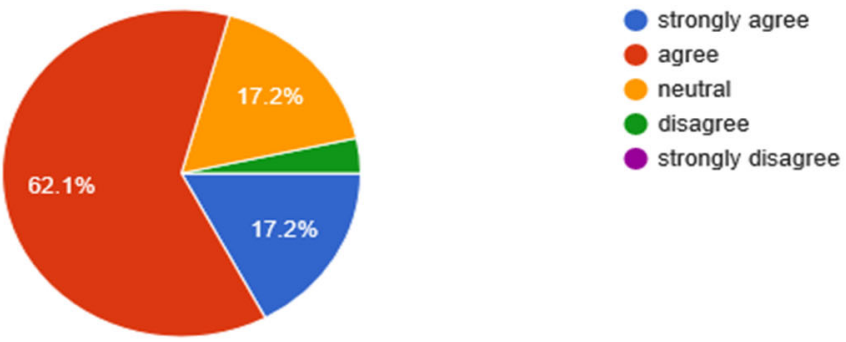

Figure 1. A Question about Structure

Another question was related to loan - words and whether they are a practical and efficient solution when the right equivalent is not known. $55.2 \%$ of the respondents said that they find opting for a loan word is useful in that case. This clarifies why they put (or create) loan - words as equivalents to English words in spite of the fact that those "loan - words) do not exist in Arabic like the loan - words they created to translate nucleic acid.

4. Using loan -words is a practical way when I do not know the right equivalent

29 responses

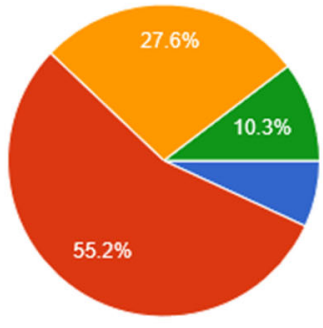

$$
\begin{aligned}
& \text { strongly agree } \\
& \text { Agree } \\
& \text { Neutral } \\
& \text { Disagree } \\
& \text { Strongly Disagree }
\end{aligned}
$$

Figure 2. A Question about Loan -Words

The next questions are related to word choice and arriving at the correct precise equivalent. As known, one of the important aspects in translating is finding the right equivalent which conveys precisely the intended meaning of the SL lexical item or expression and this importance emerges when the text is technical. To examine the students' attitude towards this issue, five questions in the survey asked about this aspect. As can be seen in the first two questions (figure 3), 41, 4\% of the students stated that translating scientific texts is difficult. In the second question above, $27.6 \%$ of the students agreed and $3.4 \%$ strongly agreed that the issue of choosing the right equivalent is highly important in technical texts more than in other types. This is justified by the fact that technical texts are normally characterized by logic and precision which means that the translator should know the right expression used in the context of the technical text the translator is working on 
6. Translating scientific terms is easy.

29 responses
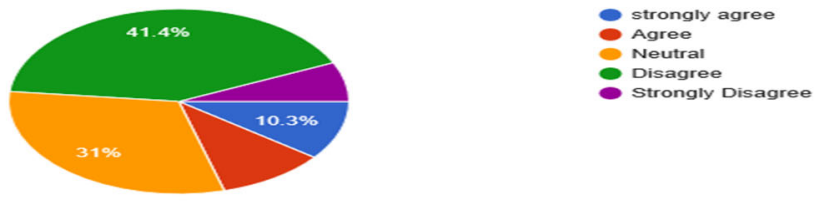

29 responses

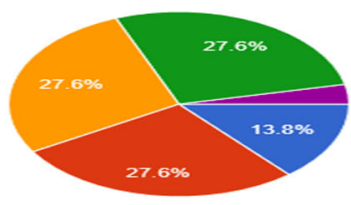

Strongly disagre

Disagree

Figure 3. Questions about Choosing the Precise Equivalent

Three more questions asked about the issue of word choice and its relation to the science to which the text belongs. As noticed in figure 4 below, $55.2 \%$ and $34.5 \%$ of the students strongly agreed and agreed respectively that the science to which the text belongs plays a major role in determining the equivalent that must be chosen. This is understood because a lexical item may mean something in one science and at the same time may have another meaning in a different science. This is clarified an in the example of translating the word shiny discussed previously.

8. The science to which the text belongs is important for determining the right equivalent. 29 responses

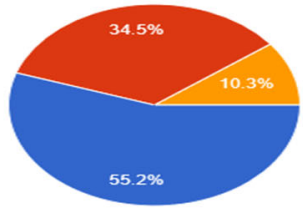

Figure 4: A question about the role of the Science in Choosing the Precise Equivalent

In the following question, (figure 5) the student were asked whether they think a word like نسيج is always translated as tissue. $34.5 \%$ strongly disagreed and $31 \%$ disagreed. This is explained by referring to the fact that the word is translated differently based on the context where it appears. For example, if it appears in a medical context where the discussion is about the body, the word tissue is used as an equivalent. On the other hand, if the discussion is related to cloth, may be texture or fabric are the right ones in that context.

9. The Arabic word (نس $)$ is always translated as (tissue) regardless of the context or the science.

29 responses

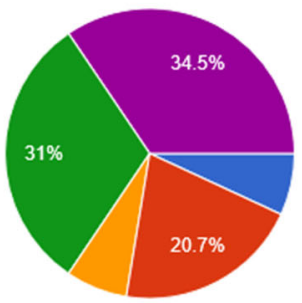

Figure 5. A Question about the Precise Equivalent of the Word نسيج

When the students were asked if choosing the right equivalent_among many_is difficult for them, the answer comes as the following: The majority $(44.8 \%)$ were neutral while those who strongly disagreed and disagreed were 
$6.9 \%$ and $24.1 \%$ respectively. On the other hand, $13.8 \%$ strongly agreed with the proposition and 10.3 agreed.

10. I have a difficulty in determining the correct equivalent of a lexical item one it has more than one meaning.

29 responses
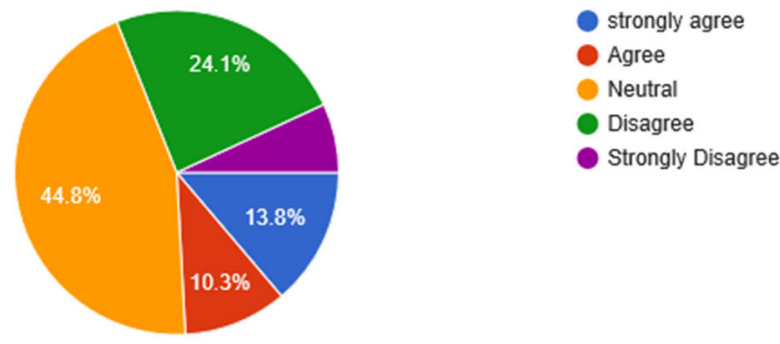

Figure 6. Question about the Difficulty of Choosing the Right Equivalent of a Word with Various Meanings

The last question was about grammar and whether it is a problem preventing them from producing the precise equivalent. As noticed from figure $6,31 \%$ of the students agreed and 24.1 strongly agreed. On the other hand, the percentage of those who did not agree is $17.2 \%$ and those who strongly disagreed were $3.4 \%$. This reflects the importance of grammar in translation side by side with the importance of opting for the right equivalent lexical item.

11. Grammatical differences is a major problem causing mistakes in translation

29 responses

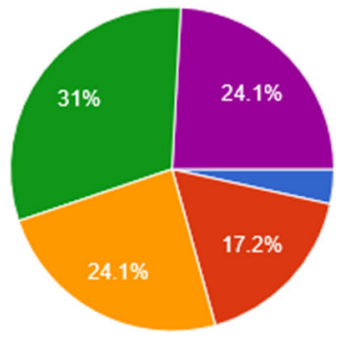

Strongly disagree
Disagree
Neutral
Agree
Strongly agree

Figure 6. Question about Grammar

\section{The Test of the Hypothesis}

As stated at the beginning of this paper, whether the specialty of the students and the studying years have an influence on the translation will be tested. It is presupposed that students coming from scientific and medical fields will produce accurate technical translation more than students coming from humanities especially if those students are third or fourth year students.

This assumption came from the fact that students studying scientific subjects are more likely to be exposed to the topics a technical translator normally faces and works and this exposition increases with the years of studying at the university.

Through the revision of the students' answers of the questionnaire, homogeneous responses were found thus indicating that the previous aspects tested are not differentiating factors. For example, when answering the question asking "translating scientific terms is easy", the students ranged their responses from neutral to disagree with only four students responding agree. Another example is when they were asked if choosing the right equivalent is highly important when translating technical texts than in other types of texts. The majority of the students answered agree and strongly disagree which means that the greatest number of those students (coming from both scientific fields and humanities and in different years) do not notice how important it is to be precise when translating a technical text. Thus, the presupposed assumption can not be approved based on the data collected from the study sample 


\section{Conclusion}

It is natural when translators are dealing with an SL and a TL belonging to two different families, they face gaps of different categories leading to unnatural outcomes if not addressed properly. This study reveals three major types of problems faced by the students when they translate technical texts. The appearance of these are even more natural when the "translator" is just a university students from which it is not excepted a highly precise translation as Farghal and shunnaq 2015 stated in their article "Major Problems in Student Translations of English Legal Texts :

"Thus it should not be taken for granted that a competent translator of general materials is of necessity a competent translator of legal texts, because there are many subtleties relating to syntax, layout and tenor that are peculiar to legal texts."

Thus, students should be given more practice and intensive training alongside highlighting the characteristics of a technical text which they must take into consideration during the process of translation.

\section{References}

Alkhuli , Muhammad Ali , Comparative linguistics : English and Arabic, Dar Alfalah, 1999.

Baalbaki, Rohi, Almawrid Dictionary, seventh edition, Dar Al-ilm Lilmalayin, 1995.

Farghal, Mohammed and Shunnaq,Abdullah, Translation with Reference to English and Arabic, Dar Al Hilal for Translation, 2011.

Farghal, Mohammed et al, Papers in Arabic/English Translation Studies1 An Applied Perspective , Farghal, Mohammed and Shunnaq ,Abdullah "Major Problems in Student Translations of English Legal Texts. The Jordanian Translators' Association, 2015.

Mahasneh, Anjad, “Arabic Language and Emotiveness's Translation”, International Journal of Social Science and Humanity, Vol. 6, No. 4, April 2016.

Murphy, Raymond, English Grammar in Use, Fourth Edition, Cambridge University Press 2012.

The dictionary English - Arabic, by Research and Studies Center, First Edition, Dar Alkotob Al- ilmiyah 2004. www.merriam-webster.com/dictionary/geyser http://www.meshaldental.net/home/?p=1742 